\title{
Konstruksi Nilai-Nilai Perempuan Metropolis Indonesia Dalam Majalah Femina
}

\author{
Dian Swandayani dan Nuning Catur Sri Wilujeng \\ Jurusan Pendidikan Bahasa Perancis, FBS, UNY \\ e-mail: dianswandayani@yahoo.com dan nuningcatursw@yahoo.com
}

\begin{abstract}
Abstrak: Subjek penelitian ini adalah rubrik "Waktu Senggang" majalah Femina tahun 2007. Tujuan penelitian ini mengungkapkan secara keseluruhan jenis-jenis film, musik, buku bacaan yang membentuk nilai-nilai citra perempuan metropolis dan kontruksi sosial. Pengumpulan data dilakukan melalui teknik baca-catat yang dikategorisasi, diinterpretasi dan dianalis secara deskriptif-kualitatif. Hasil penelitian menunjukkan bahwa: 1) film-film yang terdapat dalam rubrik "Waktu Senggang" dalam majalah Femina edisi tahun 2007 kebanyakan berupa film-film drama Hollywood; 2) jenis-jenis musik yang terdapat dalam rubrik ini adalah musik-musik pop penyanyi laki-laki; 3 ) jenis-jenis buku bacaan yang terdapat dalam rubrik ini berupa novel atau memoar/biografi dengan perempuan sebagai tokoh utamanya dan problematika-nya. Pilihan-pilihan terhadap jenis tontonan, album musik, dan buku bacaan tersebut merupakan cerminan dari masyarakat kelompok wanita metropolis dengan metropolis Amerika Serikat sebagai trend-setter. Pilihan tersebut tidak hanya sebagai citra diri majalah Femina tetapi sekaligus juga membentuk atau menjadi formasi sosial dalam membentuk cita rasa atau citra pembacanya sebagai wanita metropolis, bukan wanita kampungan yang tidak berpendidikan.
\end{abstract}

Kata kunci: citra perempuan, metropolis, majalah Femina, dan kajian budaya

\begin{abstract}
The subject of this research is rubric of "Waktu Senggang" or Leisure Time in Femina magazine in 2007. The objectives of the research are revealing all kinds of films, music, books which bend the values of metropolis women's images and social constructs. Data collecting is conducted through intensive lecture, reading documentation, then categorizing the data. The data, then, analyzed in qualitativedescriptive method. The result of the research shows that: 1) the films issued and reviewed in the rubric of "Waktu Senggang" in Femina magazine in 2007 are dominated by Hollywood movies; 2) the music genre in the same rubric are mostly pop music with male leading vocal; 3) the books that dominate the rubric are novel or memoir/ biography, which women as the principle character and their problems. The choice on the genre of show, music album, and the reader books reflects an especial female society, which is the metropolis women whom the trend setter is American metropolis women. The choice is not only to determine the self-image of Femina as a female magazine but also to construct a social form that create the taste or the image of the readers as to be the metropolis women, who are different from uneducated country women.
\end{abstract}

Key words: women image, metropolis, Femina magazine, and cultural studies.

\section{Pendahuluan}

Di Perancis ada majalah Elle yang menjadi trendsetter bagi kaum perempuan Perancis dalam mengekspresikan identitas diri mereka sebagai kaum urban metropolis. Tidak disangkal lagi bahwa media termasuk di dalamnya majalah, mempunyai peran dalam melakukan konstruksi sosial guna menanamkan nilai-nilai tertentu. Fredrick Jameson (2003) pernah menyatakan bahwa identitas seseorang ditentukan oleh apa yang dikonsumsinya. Para bintang film ternama Hollywood akan memakai baju rancangan sekelas Versace atau Giorgio Armani, makanannya di restoranrestoran berkelas dan tempat tinggalnya setidaknya di kawasan Malibu.

Identitas seseorang ditentukan oleh jenis musik yang didengarnya, film-film yang ditontonnya, buku yang dibacanya, saluran TV yang 
dinikmatinya serta tempat liburan yang ditujunya ketika musim panas maupun musim dingin. Jangan pernah menyamakan pecinta musik dangdut dengan pecinta musik klasik, mereka merasa berbeda kelas, berbeda cita rasa. Jangan samakan penikmat film-film Bollywood dengan pecinta film-film Cannes, meski mereka samasama menonton film. Citra yang ditimbulkan dari pilihan jenis film akan membuat status sosial mereka berbeda.

Perbedaan strata sosial pada era posmodern tidak lagi ditentukan hanya oleh tingkat ekonomi atau halauan pandangan hidupnya. Ada banyak faktor yang dipergunakan seseorang untuk mengekspresikan identitas dirinya, bukan tingkat kemapanan ekonomi atau etnisnya melainkan barang-barang tertentu, seperti jenis kendaraan atau HP yang dipakainya. Sering kali orang membeli sesuatu atau barang hanya demi gengsi atau status karena di era Imagologi seperti yang dikatakan oleh Kundera (2000:3), citra atau image menjadi segalanya. Orang-orang marketing mengerti benar akan arti pentingnya sebuah citra.

Majalah (di samping film, novel, lukisan, pendidikan, organisasi, hobi, tempat ibadah, jenis minuman, restoran, saluran TV, dan lainnya) merupakan situs hegemoni yang oleh Gramsci disebut sebagai tempat terjadinya pertarungan ideologi (Sugiono, 1999:60). Di dalam sebuah majalah (dan di dalam situs-situs hegemoni lainnya) tarik-menarik kekuatan berbagai ideologi dalam melakukan pengukuhan hegemoniknya ataupun sebagai sarana resistensi tengah berlangsung. Majalah tidak hanya sekedar mencerminkan ideologi para pembacanya tetapi juga sarana untuk menanamkan suatu pandangan dunia terhadap para pembacanya. Majalah juga dapat melakukan konstruksi sosial para pembacanya (Williams, 1988:243-246).

Dari sekian majalah yang beredar di Indonesia tampaknya mereka telah membidik pangsa pasarnya sendiri-sendiri. Khusus untuk pangsa pasar pembaca perempuan, Femina tampak lebih dominan di antara majalah wanita lainnya, seperti Kartini, Pertiwi, Dewi, Gadis, Female. Hal tersebut ditandai dengan besarnya oplah dan kemunculannya yang tebit setiap minggu. Lalu bagaimakah peran majalah semacam Femina dapat menggambarkan citra para pembacanya? Seberapa besar peran konstruksi sosial majalah Femina terhadap perempuan Indonesia? Masih banyak hal yang dapat diajukan sebagai pertanyaan terhadap salah satu majalah perempuan mingguan yang terbit pertama kali pada tahun 1972.

Dalam rubrik "Waktu Senggang" inilah sebetulnya sebuah "promosi" akan produk cita rasa terhadap jenis tontonan, jenis musik, jenis bacaan, dan jenis apresiasi budaya ditawarkan. Femina telah melakukan seleksi dari sekian jumlah film, CD atau kaset, buku, dan agenda seni yang ada pada setiap minggunya. Di sinilah peran konstruksi sosial itu beroperasi, bagaimana cita rasa pembaca majalah itu dibentuk. Dari rubrikrubrik semacam inilah salah satu pertarungan nilai-nilai atau ideologi bertarung. Dalam rubrik semacam inilah situs (hegemoni) citra perempuan metropolis berlangsung secara operasional. Rubrik "Waktu Senggang" berperan secara diskursif membentuk sebuah gaya hidup (lifestyle), suatu proses pendidikan terhadap nilai-nilai tertentu. Hal ini sejajar dengan pernyataan Wolf (2004:28-32) yang menyatakan bahwa kecantikan adalah sebuah kontruski sosial, sebuah mitos.

Hal-hal inilah yang akan dianalisis dan diuraikan dalam penelitian ini. Adapun permasalahan yang dibicarakan dibatasi pada halhal yang terkait dengan tema Cultural Studies. Sebagai sebuah teori, Cultural Studies atau kajian budaya yang merebak pada tahun 1990-an merupakan perkembangan yang dipelopori antara lain oleh Birmingham Center for Contemporary Cultural Studies yang berdiri pada 1963. Richard Hoggart dan Raymond Williams merupakan dua pendirinya yang notabene adalah pengajar sastra yang membuat kajian tentang bentuk-bentuk dan ekspresi budaya yang mencakup budaya tinggi ataupun rendah, dan mengemukakan sejumlah teori tentang kaitan antara keduanya sebagai formasi/konstruksi sosial historis (Storey, 2003:6882).

Penelitian ini bertujuan untuk mengungkapkan sejumlah permasalahan, seperti mendeskripsikan jenis-jenis film, musik, dan buku yang dimuat dalam rubrik "Waktu Senggang" dalam majalah Femina 2007. Berikutnya, penelitian akan mengungkap berbagai bentuk nilai-nilai citra perempuan metropolis yang terwakili dalam rubrik 
tesebut dan proses konstruksi sosial rubrik "Waktu Senggang" dalam majalah Femina 2007 terhadap masyarakat sebagai bentuk diskursus.

\section{Kajian Literatur}

Fenomena merebaknya kajian budaya (cultural studies) dilandasi oleh berbagai hal atau kondisi. Pertama, adanya keresahan akan surutnya peran kaum intelektual dalam menjawab permasalahanpermasalahan yang mendesak zamannya. Kedua, munculnya posmodernisme yang mewarnai produk budaya maupun wacana intelektual pada paruh terakhir abad ke-20. Posmodernisme membedakan diri dari seni dan wacana intelektual modern yang elitis. Seni posmodern meruntuhkan tembok pemisah antara produk budaya tinggi dan rendah dengan menciptakan karya seni yang memadukan kedua wilayah tersebut. Ketiga, maraknya perkembangan teori-teori postruktural yang membantu menghancurkan dinding pemisah antardisiplin (Budianta, 2000:52-53). Bagi sejumlah praktisi kajian budaya seperti Tony Bennett dan Laura Mulvey, kajian budaya bukanlah sekedar pemberdayaan kaum intelektual humaniora. Ada harapan bahwa kemampuan membaca juga membawa kemampuan melakukan intervensi terhadap sejumlah praktik budaya yang menekan; bahwa dengan menunjukkan daya mempermainkan atau mengelak kekangan dalam berbagai wacana budaya sehari-hari, seperti karya sastra pinggiran, graffiti, bahasa prokem dan seterusnya, kajian budaya dapat menyebarkan pemberdayaan.

Kajian budaya menurut Budianta (2000:5354) menerapkan sejumlah prinsip sebagai berikut. Pertama, kajian budaya bersifat interdisiplin atau malah anti-disiplin. Kajian budaya bersifat eklektik dalam teori yang menggabungkan sejumlah metode dan bahan kajian yang secara konvensional dimiliki oleh disiplin-disiplin tertentu. Kedua, kajian budaya menghancurkan batasan antara budaya tinggi dan rendah, dan menaruh perhatian yang serius pada budaya populer, budaya massa. Budaya populer tidak dilihat sebagai suatu produk yang rendah yang tunduk pada perintah politik atau bisnis, melainkan sebagai medium yang mempunyai potensi untuk melakukan resistensi.

Ketiga, kajian budaya menaruh perhatian pada pembaca dan konsumen. Pembaca dan konsumen budaya populer tidak dianggap sebagai penerima pasif dari budaya massa, melainkan agen yang aktif bernegosiasi dan memproduksi makna untuk kepentingan sendiri ataupun sebagai bentuk resistensi terhadap pengaruh-pengaruh dominan (Chaney, 2006:51-66).

Keempat, kajian budaya dengan sadar melihat wacananya sendiri sebagai wacana yang bermuatan politis dengan tujuan melakukan intervensi dan resistensi terhadap kekuatan politik dan ekonomi yang dominan, terutama kapitalisme global. Oleh karenanya, kajian ini seringkali terkait dengan masalah-masalah aktual dan kontemprorer, dan memperhatikan masalah produksi, konsumsi dan distribusi dalam kajian budaya (Chaney, 2006:51-66; Jaworski, 2006:146-157).

Kelima, kajian budaya melakukan redefinisi terhadap konsep kebudayaan, dan meluaskan maknanya untuk mencakup tidak hanya produkproduk budaya tinggi dan rendah, melainkan juga segala nilai dan ekspresi, praktik dan wacananya dalam "kehidupan sehari-hari" (Budianta, 2000:54; Storey, 2003:10-30). Dalam kerangka analisis kajian budaya di atas, kajian pada rubrik "Waktu Senggang" dalam majalah Femina tahun 2007 akan dibahas.

\section{Metodologi Penelitian}

Subjek penelitian ini yaitu rubrik "Waktu Senggang" majalah Femina. Adapun sampelnya yaitu rubrik "Waktu Senggang" edisi tahun 2007. Secara keseluruhan ada 51 edisi artikel yang diteliti. Teknik pengumpulan data yang dipergunakan dalam penelitian ini yaitu berupa teknik baca-catat. Data yang terkumpul kemudian dikategorisasi, dianalisis, dan diinterpretasikan. Instrumen yang dipergunakan untuk mengumpulkan data dalam penelitian ini yaitu berupa kartu data. Kartu data ini digunakan guna mempermudah pencatatan sejumlah data dan pengkategorian data.

Untuk validitas dan reliabilitas data penelitian dipergunakan teknik validitas semantis dan teknik intrarater dan interrater. Validitas semantis yaitu dengan menganalisis konteks pemaknaan terhadap teks atau naskah. Untuk reliabilitas data dipergunakan teknik intrarater, yaitu dengan cara membaca berulang-ulang sehingga diperoleh kekonsistenan data dan interrater yaitu berupa 
diskusi dengan anggota peneliti, Nuning Catung Sriwilujeng, staf pengajar PB Perancis FBS UNY.

Data yang terkumpul kemudian dianalisis secara deskriptif kualitatif. Data-data yang telah dikategorikan berdasarkan rumusan masalahnya kemudian dianalisis secara deskriptif sehingga bisa diketahui gambaran mengenai jenis-jenis film, musik, buku, dan agenda seni dalam rubrik "Waktu Senggang" dalam majalah Femina 2007 serta proses subjektivikasi dan proses konstruksi sosialnya terhadap masyarakat. Penelitian ini memfokuskan analisisnya dengan menerapkan strategi kajian budaya (cultural studies).

\section{Hasil Penelitian dan Pembahasan}

Berikut ini ditampilkan secara berturut-turut data yang terkait dengan jenis film, musik, dan buku bacaan yang terdapat dalam rubrik "Waktu Senggang".

\section{Jenis film berdasarkan produksi}

Jenis film sesuai dengan produksinya didapatkan sebagai berikut: 1) Produk Luar Negeri sebanyak 42 film, terdiri atas: Hollywood, AS (38 film), China (1 film), Korea (1 film), Spanyol (1 film), dan Thailand (1 film); 2) Produk dalam negeri sebanyak 8 (delapan) film; dan 3) Produk campuran (Indonesia dan Australis) sebanyak 1 (satu) film. Atas dasar temuan dapat disimpulkan bahwa jenis fim produksi luar negeri mendominasi pada buku bacaan yang terdapat dalam rubrik "Waktu Senggang". Selengkapnya sebagaimana tertetra pada Tabel 1 berikut.

Tabel 1. Jenis Film Berdasarkan Produksi

\begin{tabular}{|l|lr|}
\hline \multicolumn{1}{|c|}{ Film Produksi } & \multicolumn{2}{c|}{ Jumlah } \\
\hline Luar Negeri & \multicolumn{2}{r|}{42} \\
\hline 1. Hollywood, AS & 38 & \\
\hline 2. China & 1 & \\
\hline 3. Korea & 1 & \\
\hline 4. Spanyol & 1 & \\
\hline 5. Thailand & 1 & \\
\hline Dalam Negeri & & \\
\hline Campuran & & 51 \\
\hline
\end{tabular}

Catatan: Campuran film berdasarkan produksinya hanya ada di Indonesia dan Australia

Selanjutnya, jenis film berdasarkan jenisnya terdiri atas: a) Drama sebanyak 31 film; b) Animasi (5 film); c) Kisah Nyata (1 film); d) Action (7 film); d) Science fiction (2 film); dan e) Petualangan (3 film); dan f) Horor (1 film). Untuk jenis film Drama, terdiri atas: Umum ( 9 film), Sejarah (2 film), Cinta (8 film), Dokumenter (1 film), Action (5 film), Psikologis, Keluarga, dan Pattriotik (1 film).

Tabel 2. Jenis-Jenis Film

\begin{tabular}{|l|lr|}
\hline \multicolumn{1}{|c|}{ Jenis Film } & \multicolumn{2}{c|}{ Jumlah } \\
\hline Drama & \multicolumn{2}{|c|}{31} \\
\hline 1. Umum & 9 \\
\hline 2. Sejarah & 2 \\
\hline 3. Cinta & 8 \\
\hline 4. Dokumenter & 1 \\
\hline 5. Action & 5 & \\
\hline 6. Psikologis & 1 & \\
\hline 7. Keluarga & 4 & 5 \\
\hline 8. Patriotik & 1 & 1 \\
\hline Animasi & & 7 \\
\hline Kisah Nyata & & 2 \\
\hline Action & & 3 \\
\hline Science-fiction & & 2 \\
\hline Petualangan & & 51 \\
\hline Horor & & \\
\hline & & \\
Jumlah & & \\
\hline
\end{tabular}

\section{Asal dan jenis kelamin}

Temuan studi menunjukan bahwa asal film didominasi oleh film dari luar negeri (34 film: 18 film), sedangkan jenis kelamin pemain film asal luar negeri didominasi oleh kaum pria (15:11). Secara rinci dapat dilihat pada Tabel 3 berikut.

Tabel 3. Asal dan Jenis Kelamin Penyanyi

\begin{tabular}{|l|cc|}
\hline Asal dan Jenis Kelamin Penyanyi & Jumlah \\
\hline Dari Luar Negeri & \multicolumn{2}{|c|}{34} \\
\hline 1. Pria & 15 & \\
\hline 2. Wanita & \multicolumn{2}{|c|}{8} \\
\hline 3. $\varnothing$ & 11 & \\
\hline Dari Dalam Negeri & \multicolumn{2}{|c|}{18} \\
\hline 1. Pria & 11 & \\
\hline 2. Wanita & 6 & \\
\hline 3. $\varnothing$ & 1 & \\
\hline \multicolumn{2}{r}{} & \multicolumn{2}{|c|}{52} \\
\hline
\end{tabular}

Catatan: 1) Semua data berjumlah 52 karena pada edisi 20-26 Des 2007 ada dua artikel dan 2) Kode p berarti jenis kelamin tidak diketahui dengan pasti, penyanyinya campuran antara pria dan wanita, atau berupa group musik campuran pria-wanita.

\section{Jenis musik}

Hasil penelitian menunjukan bahwa Jenis musik yang dikelompokkan dalam kelompok musik: Kerokhanian, Pop, Soul, Opera/Orchestra/Big 
Band, Soundtrack Film, Rock, R \& B, Oldies, Jazz, Klasik, dan Campuran. Selanjutnya, ditemukan 1 (satu) film yang tidak dapat dikategorikan.

Tabel 4. Jenis-jenis Musik

\begin{tabular}{|l|r|}
\hline \multicolumn{1}{|c|}{ Jenis Musik } & \multicolumn{2}{c|}{ Jumlah } \\
\hline Kerohanian & 5 \\
\hline 1. Kristiani & 2 \\
\hline 2. Islam & 3 \\
\hline Pop & 16 \\
\hline Soul & 4 \\
\hline Opera/orchestra/big band & 5 \\
\hline Soundtrack film & 3 \\
\hline Rock & 2 \\
\hline R\&B & 4 \\
\hline Oldies & 2 \\
\hline Jazz & 3 \\
\hline Klasik & 2 \\
\hline Campuran & 5 \\
\hline Tidak masuk kategori & 1 \\
\hline \multicolumn{1}{|c|}{ Jumlah } & 52 \\
\hline
\end{tabular}

Catatan: 1) Jumlah data ada 52 artikel karena pada edisi 20-26 Des 2007 terdapat dua artikel dan 2) Hampir sebagian berupa gabungan berbagai elemen genre musik, data ini hanya mengkategorikan jenis musik yang dominan selain memang gabungan dari berbagai jenis musik yang dikategorikan sebagai jenis campuran.

\section{Asal dan jenis kelamin penulis}

Temuan studi menunjukan bahwa perbandingan penulis film yang berasal dari luar negeri dibandingkan dengan penulis dari dalam negeri didominasi oleh penulis film dari luar negeri (35 film: 20 film), sedangkan jenis kelamin pemain film asal luar negeri didominasi oleh kaum pria (15:11). Sebaliknya, penulis film dari dalam negeri didomnasi oleh kaum wanita (14:6). Secara rinci dapat dilihat pada Tabel 5 berikut.

Tabel 5. Asal dan Jenis Kelamin Penulis

\begin{tabular}{|c|c|}
\hline Asal dan Jenis Kelamin Penulis & Jumlah \\
\hline Dari Luar Negeri & 35 \\
\hline 1. Pria & 20 \\
\hline 2. Wanita & 15 \\
\hline Dari Dalam Negeri & 20 \\
\hline 1. Pria & 6 \\
\hline 2. Wanita & 14 \\
\hline Jumlah & 55 \\
\hline
\end{tabular}

Catatan: Semua data berjumlah 55 karena pada edisi 20-26 Des 2007 ada dua artikel dan ada 3 buku yang ditulis oleh dua orang.

\section{Jenis-Jenis Buku Bacaan}

Jenis buku-buku bacaan yang terdetksi terdiri atas: Memoar/Biografi, Novel, Sejarah, Filsafat, panduan diri, Panduan lain-lain, Kumpulan esai, Ensiklopedia, Ekologi, Ekologi, Desain Interior, Kesehatan, dan Keluarga/Perkawinan, sebagaimana tertera pada Tabel 6 berikut.

Tabel 6. Jenis-Jenis Buku Bacaan

\begin{tabular}{|l|r|}
\hline \multicolumn{1}{|c|}{ Jenis Buku Bacaan } & Jumlah \\
\hline Memoar/Biografi & 8 \\
\hline Novel & 17 \\
\hline Sejarah & 2 \\
\hline Filsafat & 1 \\
\hline Panduan Diri & 4 \\
\hline Panduan Lain-lain & 6 \\
\hline Kumpulan Esai & 3 \\
\hline Ensiklopedia & 1 \\
\hline Ekologi & 1 \\
\hline Desain Interior & 2 \\
\hline Kesehatan & 4 \\
\hline Keluarga/Perkawinan & 3 \\
\hline \multicolumn{2}{|c|}{ Jumlah } \\
\hline \multicolumn{2}{|c|}{} \\
\hline
\end{tabular}

\section{Pembahasan}

\section{Jenis-jenis Film dalam Rubrik "Waktu Senggang" Majalah Femina 2007}

Dari rubrik "Waktu Senggang" yang di dalamnya termuat informasi tentang film, ternyata hanya memuat 8 film produksi dalam negeri. Selebihnya, sebanyak 42, berupa film asing dan 1 film campuran produksi dalam negeri dengan luar negeri.

Satu film campuran tersebut berjudul "Long Road to Heaven" yakni film produksi antara Indonesia dengan Australia. Film ini mengangkat peristiwa pengeboman Bali I yang dilakukan Amrozi dan kawan-kawan dengan mengedepankan situasi seputar peristiwa tersebut khususnya dari pihak korban, di mana mayoritas berkebangsaan Australia.

Kedelapan film produksi dalam negeri yang dimuat dalam rubrik "Waktu Senggang" majalah Femina sepanjang tahun 2007 adalah: 1) "Nagabonar Jadi 2", 2) "Kala", 3) "Mengejar MasMas", 4) "Tiga Hari untuk Selamanya", 5) "The Photograph", 6) "Anak-anak Borobudur", 7) "Get Merried", dan 8) "Quickie Expresse". Tidak ada yang khusus mengusung pemikiran kaum wanita dalam film-film tersebut, apalagi mengusung pemikiran feminisme.

Temanya beragam, mulai dari permasalahan anak-anak, remaja, keluarga, hingga permasalahan antargenerasi. Permasalahan antargenerasi ini tampak dalam film "Nagabonar Jadi 
2", sebuah sekuel film patriotisme atau nasionalisme. Sekuelnya (edisi kedua) ini tidak lain mengusung permasalahan perjuangan anak bangsa terhadap penjajahan Belanda tetapi lebih berupa kelanjutan "perjuangan" setelah merdeka, perjuangan untuk mempertahankan makam istri dan sahabat Nagabonar terhadap rencana penggusuran.

Yang lebih dekat dengan permasalahan kaum perempuan yaitu film "Mengejar Mas-Mas". Dengan tokoh utamanya seorang wanita bernama Shahnaz, film ini lebih menyuarakan problematika wanita yang rentan diperkosa dan sering mengalami dilema manakala mau kawin lagi, apalagi kalau berprofesi sebagai pelacur. Berikut kutipannya.

Shahnaz (Poppy Sovia) adalah anak Jakarta yang sepeninggal ayahnya (Roy Marten), menjadi pemberontak. Sebel pada ibunya (Ira Wibowo) yang berniat kawin lagi, ia minggat menyusul kekasihnya yang sedang naik gunung. Sendirian di Yogya, ia nyaris dikerjain preman. Untung ada Ningsih (Dina Olivia), pelacur Pasar Kembang, yang menolong (bahkan mengakuinya sebagai adik) dan mengajaknya nginep di kos-kosannya. Di situ Ningsih mengaku sebagai Norman, ibu dosen yang mengajar malam hari. Di situ juga Shahnaz mengenal berbagai jenis manusia. Antara lain, Parno, pengamen dan mantan campursari kekasih Ningsih. Hidup bukan untuk dihindari, tapi untuk dipahami. Begitu tema film komedi romantic dengan dialogdialog segar itu. Sutradara Rudi Sudjarwo mampu menerjemahkan scenario cerdas Monty Tiwa, dang mengungkapnya dalam bahasa visual yang pas. Acting Dina Olivia bagus sekali (DF.24.07)

Jika dibandingkan dengan film luar negeri yang dimuat, film dalam negeri perbandingan jumlahnya cukup jauh. Dari 42 data film luar negeri hampir sebagian produksi Hollywood, Amerika Serikat. Hanya empat film luar negeri yang tidak diproduksi Barat (baca Hollywood), yakni: (1) "Curse of the Flower" (China), (2) "3 Iron" (Korea), (3) "Pan's Labyrint" (Spanyol), dan (4) "The Unseeable" (Thailand).

Di antara sekian banyak film Hollywood, di antaranya film yang berjudul "300" yang mendeskreditkan bangsa Persia (Iran) sebagai bangsa penjajah. Latar film ini berlangsung di Sparta (Yunani) zaman dahulu kala. Film ini termasuk jenis film action yang dipenuhi dengan adegan-adegan penuh kekerasan. Film ini berasal dari komik atau novel grafis. Kemunculannya mengingatkan konfrontasi Amerika Serikat (Barat) terhadap Ahmadinejad presiden Iran sebagai representasi Timur. Selain itu, ada juga film-film sekuel dari sejumlah film yang telah populer sebelumnya seperti "Die Hard 4.0", "Harry Potter and the Order of the Phoenix", atau "The Bourne Ultimatum".

Banyaknya film-film Hollywood yang dimuat dalam rubrik "Waktu Senggang" menggambarkan bahwa kiblat majalah Femina lebih berorientasi ke Barat, khususnya Amerika Serikat. Selera terhadap film Hollywood ini mengukuhkan peran dominasi Amerika yang seringkali dikenal dengan sebutan Mc Donalisasi dan Coca Colanisasi sebagai sebuah trend-setter.

Tidak ada satu pun film Bollywood (film produksi Bombay, India) yang dimuat dalam rubrik ini. Bahkan, film-film China (baik Beijing, Hongkong maupun Taiwan) tidak banyak yang dimuat dalam rubrik Waktu Senggang. Hanya ada satu film produksi China, "Curse of the Flower" yang dibintangi oleh Gong Li dan Chow Yun Fat, serta disutradarai oleh Zhang Yimau. Padahal film-film produksi India dan China secara kuantitatif lebih banyak daripada film-film Amerika.

Di pihak lain, berdasarkan jenisnya, film-film yang dimuat dalam rubrik ini kebanyakan berupa jenis film drama (Tabel 2). Ada sebanyak 31 rubrik "Waktu Senggang" yang memuat film-film drama, dengan sejumlah subvariannya seperti drama umum, drama sejarah, drama cinta, drama dokumenter, drama action, drama psikologis, drama keluarga, maupun drama patriotik. Tampaknya film jenis drama merupakan jenis film yang banyak "dianjurkan" untuk ditonton oleh para wanita pembaca majalah Femina.

\section{Jenis-jenis Musik dalam Rubrik "Waktu Senggang" Majalah Femina 2007}

Terhadap musik, Femina menawarkan lebih banyak penyanyi laki-laki daripada penyanyi wanita. Setidaknya mereka menyajikan 15 penyanyi pria asing (sementara penyanyi wanita asing hanya sebanyak 8 orang) dan 11 penyanyi 
pria dalam negeri (sementara penyanyi wanita dalam negeri hanya sebanyak 6 orang).

Tampaknya ada "kerinduan" terhadap lawan jenis dalam pilihan penyanyi. Meskipun harus diberi catatan tambahan bahwa selain kedua jenis kelamin ini masih ada sejumlah group penyanyi yang mencakup kedua jenis kelamin dan terkadang ada yang tidak teridentifikasi termasuk jenis kelamin yang mana.

Penyanyi-penyanyi (dan juga pemain musik) semacam Josh Groban, Tompi, Dave Koz, Glenn Fredly, Opick, Christian Bautista, Enrique Iglesias, Yusuf Islam, atau kelompok musik The Eagles merupakan sederet penyanyi laki-laki. Mereka tidak hanya memikat suaranya tetapi juga memikat dari seks apealnya bagi pembaca Femina. Alasan inilah yang menjadi salah satu faktor pertimbangan banyaknya penyanyi laki-laki yang muncul dalam rubrik "Waktu Senggang" jika dibandingkan penyanyi perempuan.

Dari data yang ada, rupanya jenis musik pop menjadi musik utama karena setidaknya muncul paling banyak, yakni sebanyak 16 data. Seperti halnya dengan genre film, tidak ada satupun genre musik yang secara tegas membawakan satu jenis musik. Hampir sebagian besar berupa campuran, seperti pop country, pop jazzy, rock jazzy, R\&B soul, dan lain-lain. Hal ini menandakan bahwa tidak ada pilihan jenis musik murni. Bahkan, secara eksplisit setidaknya ada 5 data yang menyatakan sebagai musik campuran seperti dalam album "JambalayaBossa America" milik Lisa Ono, "Star" milik Dewi Sandra, atau "Playful" milik Tompi.

Selain musik pop, dalam rubrik "Waktu Senggang" ini juga terdapat sejumlah jenis musik seperti soul, rock, jazz, R\&B, klasik, oldies, opera/ big band, dan soundtrack film serta lagu-lagu kerohanian. Untuk lagu-lagu kerohanian terdapat 3 album lagu kerohanian Islami dan 2 album lagu kerohanian Kristiani. Kehadirannya disesuaikan dengan konteks hari-hari raya keagamaan seperti bulan Ramadan pada album "Ya Rahman" (Opick), lebaran pada album "Semoga Jalan Dilapangkan" (Bimbo), natal pada album "Dia Sumber Gembiraku" (Djaduk Ferianto) dan "Joyful Christmas" (Ruth Sahanaya). Contoh lain album keagamaan ini yaitu milik Yusuf Islam yang berjudul "I Look, I See".
Musik-musik soundtrack film juga menjadi ciri khusus yang relatif banyak dimuat di rubrik "Waktu Senggang", antara lain seperti pada album "Soundtrack High School Musical" (Disney Channel) dan "All the Movies" (Dave Koz). Selain itu, rubrik ini juga mengusung informasi tentang album daur ulang. Hal ini juga menjadi fenomena tersendiri seperti terdapat dalam album: "Because I Love You So" (Various Artists), "The Corrs Dreams" (The Ultimate Corrs Collection), "Various Artists OST Dreamgirls", "The Best of Titi DJ" (Titi DJ), "Just A Love" (Christian Bautista), "80's Slow Dances" (Various Artists).

Fenomena berikutnya adalah munculnya tembang-tembang iringan orchestra, opera atau big band. Hal ini mengingatkan pada cita rasa tempo dulu, manakala sebuah iringan musik dibawakan dalam kelompok besar. Sekarang hampir semua kelompok band praktis hanya terdiri 4 orang: 1 penyanyi, 1 gitar ritme/pengiring/ melodi, 1 bass, dan 1 drum. Sebuah komposisi band yang sangat simpel. Contoh-contoh album big band ini terdapat pada: "Awake" (Josh Groban), "Interlude Dari Hari" (Andi Rianto), "Rockestra" (Erwin Gutawa), "Call Me Irresponsible" (Michael Buble), dan Joyful Christmas" (Ruth Sahanaya).

Secara lebih spesifik, pembaca Femina adalah pembaca yang menggemari musik pop atau sejenisnya. Ada nuansa romantika karena lebih banyak mengusung musik-musik tempo dulu ataupun musik-musik dengan iringan big band. Tentu saja hal ini berbeda dengan musik anakanak band (yang terdiri hanya 4 orang). Para pembaca Femina bukanlah pembaca yang menyukai kelompok band seperti Nidji, Peter Pan, ST12, d'Massive, Shiela On 7, dan kelompok band laki-laki sejenisnya.

Selain itu, tidak ada satu pun jenis musik dangdut/melayu yang ditawarkan dalam rubrik Waktu Senggang ini. Juga tidak terdapat musikmusik India, China, apalagi musik kasidah. Kalaupun ada musik-musik Islami, album yang mereka suguhkan adalah musuk-musik Islami yang bergaya pop seperti album Opick, Bimbo, ataupun Yusuf Islam. 
Jenis-jenis Buku Bacaan dalam Rubrik "Waktu Senggang" Femina 2007

Dari berbagai jenis buku bacaan yang ditawarkan dalam rubrik "Waktu Senggang", novel merupakan salah satu jenis bacaan yang paling banyak dimuat. Dari total 52 data yang ada, ulasan berupa novel dalam rubrik ini muncul sebanyak 17 kali. Kemudian baru disusul dengan jenis bacaan berupa memoar/biografi, lalu buku-buku panduan hidup untuk perkembangan diri atau buku panduan praktis lainnya. Selebihnya adalah bukubuku dari jenis atau bidang sejarah, filsafat, kumpulan esai, ensiklopedia, desain interior, kesehatan, dan keluarga/perkawinan.

Dilihat dari jenis kelamin penulis/pengarangnya, pengarang berjenis kelamin pria yang berasal dari luar negeri sedikit lebih banyak daripada yang berjenis kelamin wanita. Dari jumlah 35 pengarang asal luar negeri, perbandingan pengarang laki-laki dan wanitanya yaitu 20 berbanding 15. Hal tersebut berbeda pada kasus jenis pengarang dari dalam negeri. Pengarang perempuan lebih banyak daripada pengarang lakilaki, perbandingannya 14 berbanding 6 . Tampaknya tulisan-tulisan pengarang perempuan (khususnya yang dari Indonesia) lebih banyak dikonsumsi.

Mengapa novel banyak disajikan dalam rubrik "Waktu Senggang"? Indikasi ini memperlihatkan setidaknya, kaum wanita sebagai pembaca Femina, menyukai bacaan yang bersifat hiburan. Novel-novel yang dimuat dalam ulasan pendek pada rubrik ini adalah Sejarah Cinta (Nicole Krauss), Pengantin Gypsy dan Penipu Cinta (Syahmedi Dean), Map of Bones (James Roliins), Perempuan Kembang Jepun (Lan Fang), The Historian (Elisabeth Kostova), Kalatidha (Seno Gumira Ajidarma), Ana Karenina (Leo Tolstoi), Sweetness in the Belly (Camila Gibb), Mimi Ian Mintuna (Remy Sylado), Gajah Mada (Langit Kresna Hariadi), Lucia Lucia (Adriana Trigiani), Snow (Orhan Pamuk), Rate My Love (Cassandra \& Ela), Sang Alkemis (Paulo Coelho), The Inheritance of Loss (Kiran Desai), Man and Boy (Tony Parsons), dan Bordir (Marjane Satrapi). Novel-novel tersebut ditulis oleh pengarang asing dan pengarang Indonesia.

Dari novel-novel itu ada yang ditulis oleh pengarang Turki yang mendapatkan hadiah Nobel bidang sastra yaitu novel yang berjudul Snow karya Orhan Pamuk. Selain Pamuk, nama pengarang lain yang cukup populer di Indonesia antara lain: Leo Tolstoi asal Rusia dan Paulo Coelho asal Brasil. Terhadap novel Snow, Femina menuliskan ulasan pendeknya sebagai berikut.

Di sebuah kota kecil di Turki, jurnalis Turki yang lama tinggal di Jerman bernama Ka mengadakan investigasi. Ia menyelidiki tingginya angka wanita bunuh diri. Penyebabnya masih misterius, di tengah tarik-menarik ideologi sekulerisme dan tradisi agamis.

Kami menduga gadis-gadis itu bunuh diri karena adanya larangan mengenakan jilbab. Tetapi, penyelidikan itu harus menemui berbagai rintangan karena tekanan politik. Sebuah karya fiksi menumental dari seorang peraih Nobel Sastra tahun 2006, Orhan Pamuk (DB.25.07).

Dari sejumlah pengarang di atas, ada sebagian pengarang perempuan yang karyanya relatif banyak diapresiasi seperti: Lan Fang, Elisabeth Kostova, Camila Gibb, Kiran Desai, dan Marjane Satrapi. Yang menarik, ternyata dari data buku berupa novel pengarang asal Indonesia diwakili oleh pengarang-pengarang laki-laki seperti: Seno Gumira Ajidarma (Kalatidha), Remy Sylado (Mimi lan Mintuno), dan Langit Kresna Hariadi (Gajah Mada).

Novel Camila Gibb termasuk novel yang mengisahkan nasib seorang wanita di tengah budaya multikultur. Dengan tokoh utamanya seorang wanita (seperti halnya dengan Ana Karenina karya Leo Tolstoi, Perempuan Kembang Jepun karya Lan Fang, Lucia Lucia karya Adriana Trigiani, Snow karya Orhan Pamuk, ataupun Bordir karya Marjane Satrapi), novel Sweetness in the Belly lebih menyentuh dari sudut pandang wanita yang menjadi implied reader pembaca majalah Femina. Terhadap novel ini mereka mengulasnya seperti kutipan di bawah ini.

Lily, wanita keturunan Inggris, tumbuh dan dibesarkan oleh guru sufi di Maroko. Ia kemudian bekerja dan menetap di kota muslim di Harare, Ethiopia. Di situlah ia bertemu dengan pujaan hatinya, seorang dokter yang ambisius. ketika meletup konflik berkepanjangan di Ethiopia, ia mengungsi ke London. 
Lily dihadapkan pada situasi di mana identitas asal usulnya dipertanyakan. Sebuah kisah menawan tentang seorang muslim di lintas benua (DB.15.07).

Selain novel, buku bacaan lain yang banyak dimuat dalam rubrik "Waktu Senggang" ini yaitu jenis memoar atau biografi. Buku-buku yang terkategori dalam jenis ini adalah Mencari Fatima (Ghada Karmi), Women of The Beat Generation (Brenda Knight), Me, Him \& Labuan Bajo (Evy Arviantu), Cempaka Pelangi Seusai Badai (Endang TR), God's Callgirl (Carla Van Raay), The Starbucks Experience, (Joseph A. Michelli), Khadijah, The True Love Story of Muhammad (Abdul Mun'im Muhammad), dan The Hidden Face of Iran (Terence Ward).

Hampir semua buku tentang memoar dan biografi ini berkisah tentang persoalan perempuan, hanya satu yang berkisah tentang kesuksesan yakni buku yang berjudul The Starbucks Experience karya Joseph A. Michelli. Dari buku-buku Mencari Fatima hingga The Hidden Face of Iran semuanya berkisah tentang pengalaman wanita dengan berbagai konteks sosialnya.

Buku Mencari Fatima karya Ghada Karmi menceritakan perihal pengalaman seorang wanita yang terusir dari kampungnya di Jerussalem pada masa awal berdirinya Israel. Ia makin terasing setelah keluarganya terpaksa harus pindah ke London.Lewat sosok Fatima, pembantu di rumah keluarganya, Karmi melacak jejak identitasnya sebagai warga Palestina. Kisah sejarah yang mengharukan dan menuturkan pelajaran tentang kemanusiaan (DB.01.07).

Buku Me, Him \& Labuan Bajo karya Evy Arviantu menceritakan kisah tentang pengabdian seorang wanita dokter di sebuah desa terpencil, lengkap dengan bumbu romantisisme di dalamnya. Setelah menyandang gelar dokter, seorang gadis kota, Widya Prabaswari, memilih untuk bekerja sebagai dokter PTT (pegawai tidak tetap) di sebuah puskesmas kecil di desa Labuan Bajo, kabupaten Manggarai, Flores. Beragam pengalaman dan petualangan seru yang menarik, ia temukan di sana. Termasuk cintanya kepada Adi Priyatna (DB.13.07).

Buku lain yang mengangkat kisah nyata berupa catatan perjalanan dengan sudut pandang wanita juga ditemukan dalam buku yang berjudul The Hidden Face of Iran. Buku ini merupakan kisah nyata catatan perjalanan Terence Ward, warga Amerika Serikat, di negeri Iran. Ward menghabiskan masa kecilnya di Arab Saudi dan Iran. Ia kembali ke Iran, 30 tahun kemudian, untuk menelusuri kembali Negara itu, juga mencari Hassan, koki dan pengurus rumah tangga semasa ia kecil. Di buku setebal 570 halaman ini kita dapat menikmati berbagai tempat menarik, seperti Pegunungan Kurdistan, pasar loak di pusat kota Teheran atau menyusuri dataran Iran, termasuk konflik Iran dengan Negara-negara tetangga, dengan cara yang ringan (DB.39.07).

Tampaknya, baik dalam buku-buku memoar/ biografi dan beberapa novel, rubrik "Waktu Senggang" banyak menyajikan cerita dengan fokus atau tokoh utamanya seorang wanita. Hanya sebuah buku Women of The Beat Generation karya Brenda Knight yang mengupas sejarah gerakan feminis di Amerika tahun 1950-an. Tidaklah salah jika hal ini memang sesuai dengan para pembacanya yang sebagian para wanita sehingga kisah-kisah nyata seperti yang telah disebutkan di atas ataupun dalam novel-novel yang juga telah disebutkan di atas lebih terasa nuansa kewanitaannya. Meskipun untuk mengetahui apakah dalam buku-buku ini terkandung perjuangan feminisme ataukah hanya sekedar cerita dengan fokus perjuangan wanita perlu dilakukan analisis yang lebih mendalam.

Sebagian besar buku-buku yang ditawarkan dalam rubrik "Waktu Senggang" majalah Femina tahun 2007 ini lebih terfokus pada problematika wanita, baik buku-buku yang berupa novel, bukubuku memoar/biografi, buku-buku panduan praktis, ataupun dalam buku-buku jenis lainnya.

\section{Citra Perempuan Metropolis}

Dari temuan penelitian yang mengemukakan jenis film, musik dan buku yang ditampilkan dalam rubrik "Waktu Senggang" tersebut, sebetulnya majalah Femina ingin mencitrakan dirinya sebagai majalah yang para pembacanya sebagai pembaca majalah yang juga suka nonton drama-drama Hollywood, menyukai musik-musik pop yang dinyanyikan penyanyi laki-laki, dan juga gemar membaca novelnovel ataupun memoar/biografi yang mengisahkan tokoh utama perempuan dalam menghadapi problematikanya. Secara umum, baik dalam bidang musik, buku bacaan, apalagi dalam 
bidang film mereka lebih banyak mengkonsumsi produk-produk dari luar negeri.

Pembaca Femina yang diprediksi berjenis kelamin wanita bukanlah pembaca yang menggemari film-film China ataupu India. Mereka juga bukan penggemar musik dangdut, keroncong, rock, ataupun musik-musik band masa kini yang sering disebut anak band dengan jumlah personil 4 orang. Pembaca Femina diharapkan lebih menyukai jenis-jenis yang masih selaras dengan musik pop seperti jazz ataupun musik orkestra/big band. Pembaca Femina juga tidak menyukai jenis kumpulan cerpen, puisi, apalagi naskah drama. Jenis karya sastra yang mereka sukai adalah novel. Buku-buku yang terkait dengan sains tidak begitu disuka. Mereka malah lebih menyukai buku-buku panduan praktis untuk kesuksesan karir atau malah seperti Gusnaldi Instant Make-Up karya Ade Aprilia dan Serba-Serbi Menyusui karya Meidya Derni \& Orin.

Jika diambil sampel sebagai predikat pembaca Femina yang notabene sebagai citra wanita metropolis Indonesia, adalah mereka yang menonton film Dreamgirl atau Quickie Expresse, yang mendengarkan album Just A Love (Christian Bautista) atau Insomniac (Enrique Iglesias), dan yang membaca buku God's Callgirl (Carla van Raay) atau I Beg Your Prada (Alexandra Dewi dan Cynthia Agustina).

\section{Rubrik "Waktu Senggang" Majalah Femina sebagai Konstruksi Sosial}

Seperti yang telah disinggung di depan meskipun tidak secara langsung, rubrik ini tidak hanya sekedar mewakili citra majalah Femina akan pilihan tontonan terhadap film, musik, dan buku bacaan tetapi di balik itu semua ada sebuah operasi ideologis yang berusaha membentuk konstruksi sosial. Pilihan-pilihan terhadap film, album musik dan buku bacaan yang termuat dalam rubrik "Waktu Senggang" adalah pilihan dengan menggunakan cita rasa redaksinya. Pilihan-pilihan inilah yang membedakan Femina dengan majalah sejenis lainnya,.

Melalui analisis terhadap sejumlah pilihan seni tiga bidang ini setidaknya citra Femina adalah kelompok sosial tertentu yang suka menonton filmfilm drama Hollywood, suka mendengarkan album pop dengan penyanyi laki-laki yang tidak hanya merdu suaranya tetapi juga tampan dan seksi, dan suka membaca novel atau memoar yang mengisahkan perjuangan perempuan. Inilah citra majalah Femina, khususnya dari cita rasa seninya.

Akan tetapi, sebagai media massa majalah Femina tidak berhenti sebagai gambaran sebuah citra, melainkan masih memiliki peran lainnya yaitu mempengaruhi cita rasa pem-bacanya. Dengan pilihan cita rasa konsumsi seninya, majalah ini turut membentuk citra perempuan metropolis. Secara tidak langsung pilihan redaksi Femina adalah kelanjutan promosi terhadap film, album musik, dan buku bacaan. Secara tidak langsung, Femina turut mem-pengaruhi pembaca untuk memilih film-film drama Hollywood, mendengarkan musik-musik pop yang jazzy produksi luar negeri, dan membaca novel atau memoar/biografi dengan tokoh utamanya wanita.

Hal-hal inilah yang dinamakan sebagai konstruksi sosial yang dibawa oleh media massa sebagai situs hegemoni. Apa yang dilakukan Femina dalam memberikan panduan bagi pembacanya untuk memilih konsumsi film, musik, dan buku bacaan seperti yang terdapat dalam rubrik "Waktu Senggang" termasuk salah satu jenis formasi sosial. Bentuk rubrik itu sendiri hanya terdiri dari satu halaman. Oleh karenanya, hanya berupa ulasan kecil atau ulasan pendek. Belum lagi dalam setiap edisinya selalu disertai dengan ilustrasi adegan film yang cukup besar sehingga mengambil porsi cukup besar.

Meskipun berupa ulasan singkat, tidak berarti kalah efektif dalam mempengaruhi pembacanya dibandingkan dengan resensi yang utuh satu halaman, baik dalam resensi film, musik, ataupun buku. Hanya untuk mengukur seberapa efektif dan seberapa besar pengaruh rubrik ini terhadap pembacanya perlu penelitian tersendiri.

"Waktu Senggang" yang menjadi nama rubrik dalam majalah Femina ini tidak hanya menyatakan tentang waktu senggang bagi para wanita yang habis bekerja lalu mengisinya dengan menonton film, mendengarkan musik, atau membaca buku pilihan seperti yang disarankan. Sekali lagi bukan sekedar mengisi waktu luang. Rubrik "Waktu Senggang" merupakan salah satu pembentukan citra, pembentukan cita rasa baik terhadap keberadaan majalah Femina itu sendiri maupun terhadap citra dan cita rasa para pembacanya. 
Para pembaca Femina adalah pembaca wanita metropolis. Mereka adalah sekelompok orang yang tidak mau menonton film India atau China, kalaupun menonton film Indonesia haruslah disortir dahulu. Mereka bukanlah penikmat musik dangdut ataupun keroncong, apalagi kasidah. Mereka juga bukan pembaca buku-buku yang serius dan ilmiah, tetapi sebagai kelompok yang suka membaca novel, bukan puisi atau teks drama.

Itulah selera wanita metropolis yang berorientasi seni metropolis Amerika. Inilah salah satu bentuk diskursus atau wacana yang dibangun dalam membentuk komunitas metropolitan. Identitas seseorang seringkali ditunjukkan dengan jenis kendaraan yang dikendaraianya, merk baju tertentu yang dipakainya, deretan menu makanan yang disantapnya, juga termasuk film apa yang ditontonnya, musik apa yang didengarnya, serta buku apa yang dibacanya. Rubrik "Waktu Senggang" telah mengambil peran diskursus tersebut.

\section{Simpulan dan Saran Simpulan}

Berdasarkan uraian di atas, dapat disimpulkan sejumlah temuan sebagai berikut. Pertama, filmfilm yang terdapat dalam rubrik "Waktu Senggang" dalam majalah Femina edisi tahun 2007 kebanyakan berupa film-film drama Hollywood. Kedua, jenis-jenis musik yang terdapat dalam rubrik ini yaitu musik-musik pop penyanyi laki-laki. Ketiga, jenis-jenis buku bacaan yang terdapat dalam rubrik ini yaitu berupa novel atau memoar/ biografi dengan perempuan sebagai tokoh utamanya dan problematikanya. Keempat, pilihanpilihan terhadap jenis tontonan, album musik, dan buku bacaan tersebut adalah cerminan dari masyarakat kelompok wanita metropolis dengan metropolis Amerika Serikat sebagai trendsetternya. Kelima, pilihan tersebut tidak hanya sebagai citra diri majalah Femina tetapi sekaligus juga membentuk atau menjadi formasi sosial dalam membentuk cita rasa atau citra pembacanya sebagai wanita metropolis, bukan wanita kampungan yang tidak berpendidikan.

\section{Saran}

Rubrik "Waktu Senggang" yang terdapat dalam majalah Femina tidak hanya berupa refleksi citra kaum perempuan metropolis Indonesia. Melalui ulasan singkat terhadap perkembangan dunia film, musik, dan buku bacaan dalam majalah ini, pembaca juga dikonstruksi untuk memiliki cita rasa seperti yang dibawa oleh Femina yang mengikuti trend setter budaya perempuan metropolis Amerika. Oleh karena itu, perlu adanya sikap kritis pembaca dalam "mengkonsumsi atau mencerna" bacaan Femina, khususnya dalam rubrik "Waktu Senggang" sehingga tidak secara otomatis mengikuti perkembangan trend budaya populer. Meskipun harus ditambahkan pada bagian ini bahwa tidak selamanya budaya populer itu lebih rendah nilainya dibandingkan budaya mainstreams. Yang perlu dikritisi terhadap budaya trend setter populer itu janganlah ditiru secara membabi buta atau latah, tetapi dengan kesadaran kritis terhadap nilai-nilai yang diusung bersamanya.

\section{Pustaka Acuan}

Budianta, Melani.,2000. "Teori Sastra Sesudah Strukturalisme: dari Studi Teks ke Studi Wacana Budaya," Teori dan Kritik Sastra. Jakarta:Lembaga Penelitian Universitas Indonesia.

Chaney, David., 2006. Lifestyle Sebuah Pengantar Komprehensif. Yogyakarta: Jalasutra.

Jameson, Fredric., 2003. "Future City," New Left Review. Edisi no 21, Mei-Juni 2003.

Jaworski, Adam dan Nikolas Coupland (ed.)., 2006. The Discourse Reader. London dan New York: Routledge.

Kundera, Milan., 2000. Kitab Lupa dan Gelak Tawa. Yogyakarta: Bentang.

Storey, John.,2003. Teori Budaya dan Budaya Pop. Penyunting bahasa Indonesia oleh Dede Nurdin. Yogyakarta: Qalam.

Sugiono, Muhadi.,1999. Kritik Antonio Gramsci Terhadap Pembangunan Dunia Ketiga. Yogyakarta: Pustaka Pelajar.

Williams, Raymond., 1988. "Dominant, Residual, and Emergent," dalam K.M. New-ton, Twentieth Century Literary Theory. London: Macmillan Education Ltd.

Wolf, Naomi., 2004. Mitos Kecantikan Kala Kecantikan Menindas Perem-puan. Yogya-karta: Niagara. 